\title{
Presence of $t(14 ; 18)$ translocation in healthy individuals varies according to ethnic background in the Brazilian population
}

\author{
D. Levy ${ }^{1}$, E.R.M. Bertoldi ${ }^{1}$, J.L.M. Ruiz ${ }^{2}$, J. Pereira ${ }^{1}$ and S.P. Bydlowski ${ }^{1}$ \\ ${ }^{1}$ Laboratório de Genética e Hematologia Molecular (LIM31), Faculdade de Medicina, Universidade de São Paulo, \\ São Paulo, SP, Brasil \\ ${ }^{2}$ Universidade Federal da Integracão Latino-Americana, Porto Belo, Foz do Iguaçu, PR, Brasil
}

\begin{abstract}
Several groups have demonstrated that healthy individuals can present the $t(14 ; 18)$ translocation. In this report, the presence of the translocation was examined in healthy blood donors in Brazil, a country considered an ethnic melting pot. The translocation was detected by nested PCR in 227 peripheral blood samples from individuals with different ethnic backgrounds. The $t(14 ; 18)$ translocation was found in 45 of 85 White individuals (52.94\%); in 57 of 72 Black individuals (79.17\%); and in 68 of 70 individuals $(97.14 \%)$ of Japanese-descent. In conclusion, the frequency of the $t(14 ; 18)$ translocation in the Brazilian population varies according to the ethnic background.
\end{abstract}

Key words: t(14;18); Lymphomas; Characterization; Molecular genetics

\section{Introduction}

The chromosomal translocation involving the long arms of chromosomes 14 and 18 has been detected cytogenetically in about $90 \%$ of follicular lymphomas and $20-30 \%$ of diffuse large cell lymphomas (1). The $t(14 ; 18)$ translocation involves the $b c / 2$ gene, which is translocated into the immunoglobulin heavy $(\mathrm{lgH})$ chain locus (2). As a result, bcl2 expression is controlled by the promoter of the constitutive $\mathrm{IgH}$ leading to high transcription levels of this chimeric RNA. The coding sequence of the $b c / 2$ transcript is not altered and the resulting protein is identical to that from the normal gene (3). Nearly $60 \%$ of the $t(14 ; 18)$ translocations are clustered within a $166 \mathrm{bp}$ sequence of the so-called major breakpoint region (MBR) (4).

The unusually high levels of $b c / 2$ create $t(14 ; 18)$ positive $B$ lymphocytes that can accumulate and escape from their natural control mechanism. The $t(14 ; 18)$ translocation is not sufficient for lymphoma development, as demonstrated by the presence of $t(14 ; 18)$-positive lymphocytes in healthy individuals (5). This translocation is the same found in follicular lymphoma (1). More than $50 \%$ of Western European and North American healthy individuals have circulating B-cells that carry this translocation (2). Nevertheless, the percentage of healthy individuals carrying the $t(14 ; 18)$ translocation varies greatly among different populations $(1,5,6)$.
There are significant differences in the frequency of the $t(14 ; 18)$ translocation in populations from different countries. To the best of our knowledge, there are no studies in Black populations. Brazil is a country with a known ethnic diversity, which allows analyses of different genetic profiles. The frequency of the $t(14 ; 18)$ translocation was $74 \%$ in patients with follicular lymphoma when determined by fluorescence in situ hybridization (FISH) (7). However, no data on the Brazilian healthy population have been reported. Here, we describe the frequency of the $t(14 ; 18)$ translocation in a Brazilian population of healthy individuals with different ethnic backgrounds.

\section{Material and Methods}

\section{Population samples}

A total of 227 peripheral blood samples were collected from subjects ranging from 18 to 71 years old. The samples were collected from healthy blood donors from Fundação Pró-Sangue Hemocentro de São Paulo, after they signed a written informed consent form, according to the protocol approved by the Ethics Committee on Human Research of the institutions. Subjects were asked about their ethnicity as previously described by our group (8). 


\section{DNA isolation and nested PCR}

DNA from peripheral blood mononuclear cells was extracted from $500 \mu \mathrm{L}$ of whole human blood samples using a salting out method with slight modifications, as previously described (9). DNA from a follicular lymphoma patient was used as a positive control. Karpas- 422 cell dilutions were used to calculate the PCR detection limit. For nested PCR, the MBR of the $t(14 ; 18)$ translocation was amplified by a two-step nested PCR as previously described (10).

The following pairs of oligonucleotides (Integrated DNA Technologies, USA) were used: first step - sense: 5'-GAC CAG CAG ATT CAA ATC TAT GGT GGT-3'; antisense: $5^{\prime}$-GGA CTC ACC TGA GGA GAC GGT G -3'; second step - sense: $5^{\prime}$-CCT TTA GAG AGT TGC TTT ACG TGG CC-3'; antisense: 5'-GGA GAC GGT GAC CAG GGT-3'.

The first step of PCR amplification was performed in a $50-\mu \mathrm{L}$ reaction mixture containing $500 \mathrm{ng}$ genomic DNA, $0.36 \mu \mathrm{M}$ of each first step primer, $0.2 \mathrm{mM}$ dNTP, $1.50 \mathrm{mM}$ $\mathrm{MgCl}, 50 \mathrm{mM} \mathrm{KCl}, 10 \mathrm{mM}$ Tris- $\mathrm{HCl}, \mathrm{pH} 8.3$, and $0.5 \mathrm{U}$ Taq DNA polymerase using a PT100 JM Research thermocycler. Conditions were 25 cycles at $95^{\circ} \mathrm{C}$ for $30 \mathrm{~s}, 54^{\circ} \mathrm{C}$ for $40 \mathrm{~s}, 72^{\circ} \mathrm{C}$ for $45 \mathrm{~s}$.

The second step was performed in a $50-\mu \mathrm{L}$ reaction mixture containing $3 \mu \mathrm{L}$ of the PCR product obtained in the first reaction, $0.48 \mu \mathrm{M}$ of each second step primer, $0.2 \mathrm{mM}$ each dNTP, $1.50 \mathrm{mM} \mathrm{MgCl}, 50 \mathrm{mM} \mathrm{KCl}, 10 \mathrm{mM}$ Tris- $\mathrm{HCl}$,

A

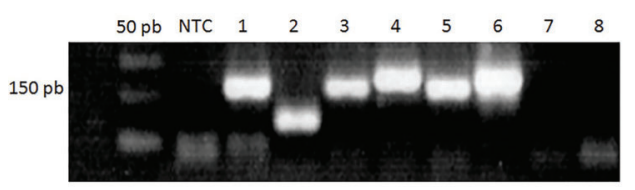

B

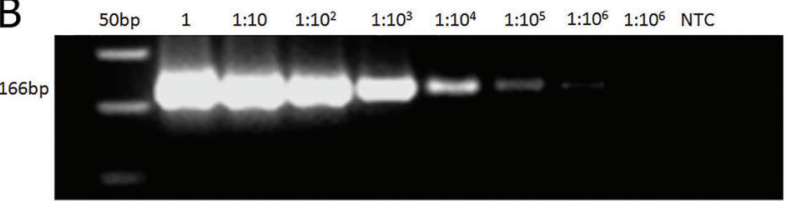

Figure 1. Nested PCR of bcl-2/lGH rearrangement. $A$, Amplification products of NTC (no template control); 1-6: positive subjects; 7 and 8: negative subjects. $B$, Detection limits of $b c / 2 / \mathrm{lgH}$ rearrangement test. Karpas- 422 cells were increasingly diluted with bcl2/lGH negative cells. Detection limit was $1: 10^{6}$ dilution.
$\mathrm{pH}$ 8.3, and 0.5 U Taq DNA polymerase. Thermocycler conditions were 30 cycles at $95^{\circ} \mathrm{C}$ for $30 \mathrm{~s}, 55^{\circ} \mathrm{C}$ for $40 \mathrm{~s}$, $72^{\circ} \mathrm{C}$ for $45 \mathrm{~s}$. Amplification products were analyzed by electrophoresis on $3 \%(\mathrm{w} / \mathrm{v})$ agarose gel after staining with gel red (Figure 1A).

Karpas-422 cell dilutions were used to test the detection limit with a reproducible detection of one $t(14 ; 18)$ copy in $105(1: 100,000)$ cells and a maximum detection limit of $1: 106(1: 1,000,000)$ cells (Figure 1B). The detection limits were very similar to those described by Schmitt el al. (10) confirming the robustness of this nested PCR.

\section{Statistical analysis}

The $X^{2}$-test was used to evaluate differences between groups (Software: GraphPad Prism 5, USA).

\section{Results and Discussion}

Studies have associated follicular lymphoma risk factors with the prevalence and/or frequency of $t(14 ; 18)$ positive cells in individuals without lymphoma (3). The presence of the $\mathrm{BCL} 2 / \mathrm{lgH}$ rearrangement in the peripheral blood of healthy individuals is well documented $(3,11)$. In this study, the frequency of the $t(14 ; 18)-M B R$ translocation was determined in 227 DNA samples from normal individuals using nested PCR.

Brazilians are one of the most heterogeneous populations in the world due to extensive admixture of three different ancestral roots: American Indians, Europeans, and Africans (12). Japanese immigration is more recent. The Brazilian population is $62.6 \%$ White, $5.8 \%$ Black, $30.8 \%$ Mulatto, and $0.8 \%$ Japanese-descendants (8). The ethnic composition of the subjects in this study is summarized in Table 1. Eighty-five individuals were White (median age: 45 years; $43.53 \%$ male), 72 were Black (median age: 45 years; $50.00 \%$ male), and 70 were Japanese-descendants (median age: 34.5 years; $47.14 \%$ male).

There are large discrepancies in the frequencies of the $\mathrm{BCL} 2 / \mathrm{lgH}$ translocation reported in healthy subjects, ranging from 8 to $88 \%$, according to Schüler et al. (2) The variability between studies is mainly due to the sensitivity of the technique, the initial concentration of DNA, and the tissue origin $(2,13)$. However, there are factors not related to experimental variations, such as the age of the individual (10), exposure to pesticides (14), the

Table 1. Age and gender of the individuals evaluated for the $t(14 ; 18)$ translocation, according to ethnic group.

\begin{tabular}{lccccc}
\hline & \multicolumn{2}{c}{ Age } & & \multicolumn{2}{c}{ Gender } \\
\cline { 2 - 3 } \cline { 5 - 6 } & Median & Range & & Male & Female \\
\hline White $(n=85)$ & 45.0 & $19-71$ & & $37(43.53 \%)$ & $48(56.47 \%)$ \\
Black $(n=72)$ & 32.5 & $19-56$ & & $54(75.00 \%)$ & $18(25.00 \%)$ \\
Japanese descendant $(n=70)$ & 34.5 & $18-63$ & & $33(47.14 \%)$ & $37(52.86 \%)$ \\
\hline
\end{tabular}




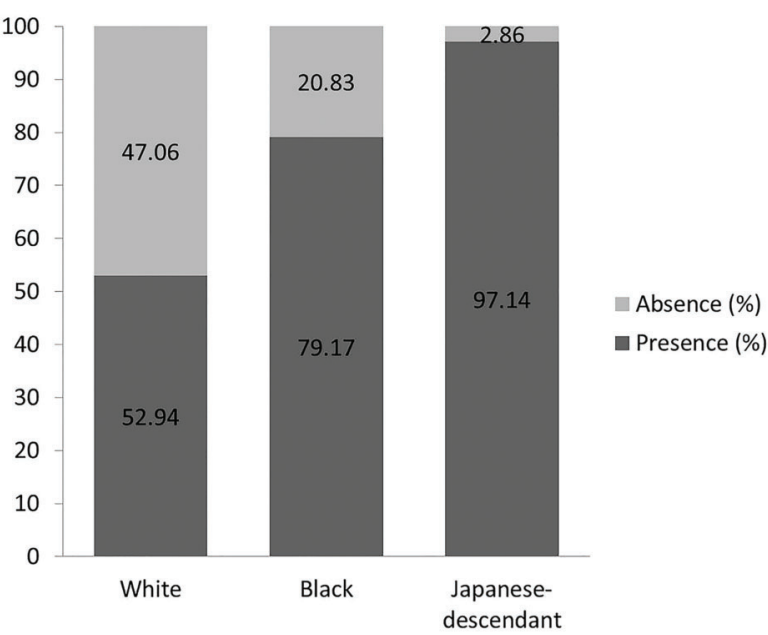

Figure 2. Frequency of $t(14 ; 18)$ translocation in different ethnic groups, as determined by nested-PCR. The $\mathrm{X}^{2}$-test was used to demonstrate differences between groups.

family history of hematopoietic diseases (14), smoking (3), and others.

In our study, the t(14;18)-MBR translocation frequency varied between the ethnic groups. The translocation was found in $52.94 \%$ White individuals, $79.17 \%$ Black individuals, and in $97.14 \%$ of the Japanese-descendants (Figure 2). The frequency in White subjects was similar to values previously reported. This is the first description of the $t(14 ; 18)-M B R$ translocation frequency in a Black

\section{References}

1. Dölken G, Dölken L, Hirt C, Fusch C, Rabkin CS, Schüler F. Age-dependent prevalence and frequency of circulating $t(14 ; 18)$-positive cells in the peripheral blood of healthy individuals. J Natl Cancer Inst Monogr 2008; 39: 44-47, doi: 10.1093/jncimonographs/lgn005.

2. Schüler F, Hirt C, Dölken G. Chromosomal translocation $t(14 ; 18)$ in healthy individuals. Semin Cancer Biol 2003;13: 203-209, doi: 10.1016/S1044-579X(03)00016-6.

3. Hirt C, Weitmann K, Schuler F, Kiefer T, Rabkin CS, Hoffmann W, et al. Circulating $t(14 ; 18)$-positive cells in healthy individuals: association with age and sex but not with smoking. Leuk Lymphoma 2013; 54: 2678-2684, doi: 10.3109/10428194.2013.788177.

4. Buchonnet G, Lenain P, Ruminy P, Lepretre S, Stamatoullas $A$, Parmentier F, et al. Characterisation of BCL2-JH rearrangements in follicular lymphoma: PCR detection of $3^{\prime}$ BCL2 breakpoints and evidence of a new cluster. Leukemia 2000; 14: 1563-1569, doi: 10.1038/sj.leu.2401889.

5. Chang CM, Wang SS, Dave BJ, Jain S, Vasef MA, Weisenburger DD, et al. Risk factors for non-Hodgkin lymphoma subtypes defined by histology and $t(14 ; 18)$ in a population-based case-control study. Int J Cancer 2011; 129: 938-947, doi: 10.1002/ijc.25717. population, and the frequency was higher than in the White population. One unexpected observation from our study was the high frequency of the translocation in Japanese-descendants. Few studies have been performed in Japanese populations. A low frequency $(15.45 \%)$ of the $\mathrm{BCL} 2 / \mathrm{lgH}$ translocation was detected in peripheral blood lymphocytes of healthy Japanese individuals (15). Another study of Chinese individuals of the Han nationality, located in the Zhejiang area, reported a translocation frequency of $9.66 \%$ (6). The Japanesedescendant population in Brazil is mostly from Okinawa Island. The population of this island represents $1 \%$ of Japan's population. There are no data available for the population of Okinawa. Nevertheless, the difference in the frequency found in this study is likely to be due to geographical segregation.

In conclusion, we demonstrated that the frequency of the $t(14 ; 18)-M B R$ translocation in Brazil varied according to the individual's ethnic origin. The highest (97.14\%) frequency was found in Japanese descendants, while an intermediate frequency $(79.17 \%)$ was detected in the Black population and the lowest frequency $(52.94 \%)$ in the White population. Therefore, this translocation is not considered a good marker for follicular lymphoma in Brazil.

\section{Acknowledgments}

This work was supported by a grant from Conselho Nacional de Desenvolvimento Científico e Tecnológico (CNPq), Brazil; and by the Instituto Nacional de Ciencia e Tecnologia - Fluidos Complexos (INCT-FCX), Brazil.

6. Liang Y, Zhou R, Ye YF, Xie Y, Mao ZR. [BCL-2/lgH translocation in peripheral blood cells of healthy Chinese individuals of Han nationality located in Zhejiang area]. Chinese $\mathrm{J}$ Med Genetics 2005; 22: 548-550.

7. Duarte IX, Domeny-Duarte P, Wludarski SC, Natkunam Y, Bacchi CE. Follicular lymphoma in young adults: a clinicopathological and molecular study of 200 patients. Mod Pathol 2013; 26: 1183-1196, doi: 10.1038/modpathol.2013.50.

8. Bydlowski SP, de Moura-Neto RS, Soares RP, Silva R, Debes-Bravo AA, Morganti L. Genetic data on 12 STRs (F13A01, F13B, FESFPS, LPL, CSF1PO, TPOX, TH01, vWA, D16S539, D7S820, D13S317, D5S818) from four ethnic groups of São Paulo, Brazil. Forensic Sci Int 2003; 135: 67-71, doi: 10.1016/S0379-0738(03)00174-9.

9. Alessio AC, Hoehr NF, Siqueira LH, Bydlowski SP, AnnichinoBizzacchi JM. Polymorphism C776G in the transcobalamin II gene and homocysteine, folate and vitamin B12 concentrations. Association with MTHFR C677T and A1298C and MTRR A66G polymorphisms in healthy children. Thromb Res 2007; 119: 571-577, doi: 10.1016/j.thromres.2006. 05.009 .

10. Schmitt C, Balogh B, Grundt A, Buchholtz C, Leo A, Benner $\mathrm{A}$, et al. The bcl-2/lgH rearrangement in a population 
of 204 healthy individuals: occurrence, age and gender distribution, breakpoints, and detection method validity. Leuk Res 2006; 30: 745-750, doi: 10.1016/j.leukres.2005.10.001.

11. Pan $Y$, Meng $B$, Sun $B$, Guan $B$, Liang $Y$, Wang $H$, et al. Frequencies of BCL2 and BCL6 translocations in representative Chinese follicular lymphoma patients: morphologic, immunohistochemical, and FISH analyses. Diagn Mol Pathol 2012; 21: 234-240, doi: 10.1097/PDM.0b013e31 $82585 \mathrm{c} 3 \mathrm{c}$.

12. Durso DF, Bydlowski SP, Hutz MH, Suarez-Kurtz G, Magalhaes TR, Pena SD. Association of genetic variants with self-assessed color categories in Brazilians. PloS One 2014; 9: e83926, doi: 10.1371/journal.pone.0083926.
13. Ismail SI, Sughayer MA, Al-Quadan TF, Qaqish BM, Tarawneh MS. Frequency of $t(14 ; 18)$ in follicular lymphoma patients: geographical or technical variation. Int J Lab Hematol 2009; 31: 535-543, doi: 10.1111/j.1751-553X.2008.01075.x.

14. Chiu BC, Dave BJ, Blair A, Gapstur SM, Zahm SH, Weisenburger DD. Agricultural pesticide use and risk of $\mathrm{t}(14 ; 18)$-defined subtypes of non-Hodgkin lymphoma. Blood 2006; 108: 1363-1369, doi: 10.1182/blood-2005-12-008755.

15. Yasukawa M, Bando S, Dölken G, Sada E, Yakushijin Y, Fujita $S$, et al. Low frequency of $B C L-2 / J(H)$ translocation in peripheral blood lymphocytes of healthy Japanese individuals. Blood 2001; 98: 486-488, doi: 10.1182/blood.V98. 2.486 . 